\title{
« Productivity, resource endowment and trade performance of the wood product sector "
}

\author{
$\underline{\text { Auteurs }}$ \\ Bertrand Koebel, Anne-Laure Levet, Phu Nguyen-Van, Indradev Purohoo, \\ Ludovic Guinard
}

Document de Travail $n^{\circ} 2015-26$

Novembre 2015

Faculté des sciences économiques et de gestion

Pôle européen de gestion et d'économie (PEGE) 61 avenue de la Forêt Noire F-67085 Strasbourg Cedex

Secrétariat du BETA

Géraldine Del Fabbro Tél. : (33) 0368852069 Fax : (33) 0368852070 g.delfabbro @unistra.fr www.beta-umr7522.fr 


\title{
Productivity, resource endowment and trade performance of the wood product sector
}

\author{
Bertrand M. Koebel ${ }^{a}$, Anne-Laure Levet ${ }^{b}$, Phu Nguyen-Van ${ }^{a}$, \\ Indradev Purohoo ${ }^{b}$, and Ludovic Guinard ${ }^{b}$ \\ ${ }^{a}$ BETA, CNRS and Université de Strasbourg \\ ${ }^{b}$ FCBA, Cité Descartes - Paris Est
}

$21^{\text {st }}$ October 2015

\begin{abstract}
This paper analyzes the determinants of international trade of wood products, considering three main groups: woodworking products, pulp and paper and wooden furniture. We extend the Heckscher-Ohlin-Vanek (HOV) framework in order to take into account the forest resource endowment as well as industrial performance factors. Empirical tests are based on data on European countries between 1995 and 2007. The HOV hypothesis is partially confirmed in that the forest resource endowment is a significant determinant for explaining differences in net trade of two products (pulp and paper and furniture) but not for woodworking products. In addition, empirical tests also show the limits of the HOV model for explaining international trade of wood products. Indeed, factors reflecting industrial performance of wood sectors, including total factor productivity and average labor cost, have a significant role in determining differences in net trade of wood products.
\end{abstract}

Keywords: Heckscher-Ohlin-Vanek hypothesis; international trade; wood products, panel data.

JEL Classification: F10; L60; Q23 


\section{Introduction}

From an economic viewpoint it may be paradoxical that countries with similar forest endowments have quite different trade balances for wood products. An important part of the literature still explains international trade between countries by differences in endowment of production factors using the Heckscher-Ohlin model (Krugman, Obstfeld and Melitz, 2010). More precisely, countries for which the required production factors are relatively abundant have comparative advantages in the production of those goods, and therefore export them (Heckscher 1919, Ohlin 1933). The multi-factor and multi-product framework has been developed by Vanek (1968) and is known as the Heckscher-Ohlin-Vanek (HOV) model. In the forestbased sector, the HOV model predicts that a country with relatively more abundant forest resource will also have larger net exports of wood products other things being equal (Prestemon and Buongiorno, 1997).

However, if we consider the main exporting countries of wood products, it appears that there is no systematic correlation between the forest resource and the trade balance of wood products (see Figure 1). At a comparable level of forest resource (measured in hectares per inhabitant), some countries benefit from a positive trade balance of wood products (Germany, Austria, Italy, etc.) whereas others suffer from a deficit (France, Japan, USA).

This paradox is comparable to the one discussed by Leontief, which took about three decades to be understood by economists (see Feenstra, 2004 for a literature review). One solution to the paradox has been provided by Leamer (1980) who proposed a correct statement of the link between trade and factor endowments using the HOV model. A second solution allowing a better understanding of the determinants of trade was to introduce industry specific heterogeneity across countries (Trefler, 1993 and Davis and Weinstein, 2001). We follow these recommandations, and propose a model explaining the trade balance for wood products as a function of forest resource endowments, but also time and industry specific variables. Our main purpose is to shed new light on why countries with comparable forest resources have different trade performances.

Compared to the existing literature (Bonnefoi and Buongiorno 1990, Lundmark 2010, Prestemon and Buongiorno 1997, Uusivuori and Tervo 2002), our empirical analysis considers the forest resource endowment for explaining international trade of wood products, but also other factors with particular emphasis on the industrial performance indicators. Furthermore, this paper considers processed and finished wood products (woodworking products, pulp, paper and paperboard, furniture) whereas, so far, the literature was more focused on forest products (roundwood) and first processed products (pulp, panel).

The paper is organized as follows. The next section gives an overview of the international trade in wood products as well as its evolution since 1995 based on UN Comtrade data. The international competitiveness of the main export countries is also analyzed through market shares and net exports. Section 3 describes the data. Section 4 presents an econometric model for assessing the Heckscher-OhlinVanek (HOV) hypothesis. In addition, the objective is to analyze the importance of industrial performance indicators in the explanation of the trade performance 


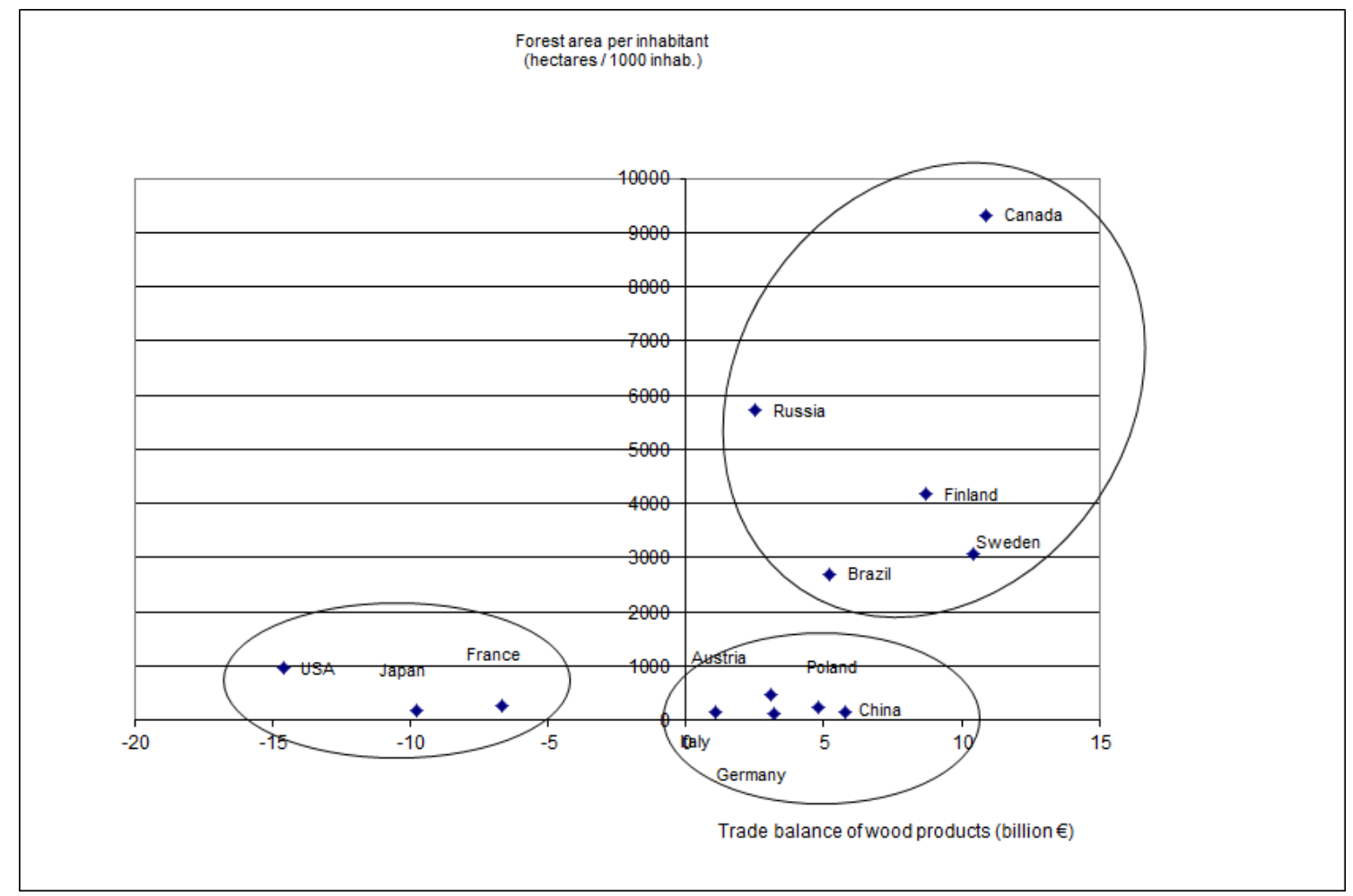

Figure 1: Trade balance and forest area. Data sources: UN Comtrade and FAO 2010 .

of exporting countries with a focus on total factor productivity (TFP). Section 5 discusses the results and draws some recommendations. Section 6 concludes.

\section{International trade of wood products}

In this paper, wood products include all forest-based and wood products from the forest (roundwood) to finished wood products. We split them into four main groups reflecting their type of industrial transformation (see Table A1 in the Appendix). This classification is consistent with the database nomenclatures which are commonly used for analyzing international trade of commodities and their related industrial sectors. The world exports of wood products accounted 442 billion dollars in 2011, which represents 2,3 percent of the total international trade of commodities. Their amount increased by $105 \%$ in comparison to 1995 . The trade in value is largely dominated by processed wood products (with higher added value) whereas rough wood is marginal. Pulp and paper products represent more than the half of total exports (54\% in 2011) followed by woodworking products (23\% in 2011) and furniture (20\% in 2011). The share of harvested wood products was about $3 \%$ of total trade. These shares are relatively stable since 2000 .

Table 1 shows that the most important exporters of wood products are mainly traditional forest countries from North America and Europe (USA, Canada, Sweden, Finland, Germany). In particular, these countries are very performent in exporting pulp, paper and paperboard as well as woodworking products (especially elements of 
Table 1: Export market shares (percent) in 1995, 2000 and 2011 - all wood products

\begin{tabular}{lrrr}
\hline \hline Countries & 1995 & 2000 & 2011 \\
\hline China & 1.4 & 2.3 & 12.0 \\
Germany & 9.1 & 8.2 & 11.8 \\
USA & 12.0 & 11.1 & 10.1 \\
Canada & 14.8 & 15.1 & 7.5 \\
Sweden & 6.5 & 5.2 & 5.5 \\
Italy & 5.2 & 4.9 & 4.9 \\
Poland & 1.2 & 1.6 & 4.0 \\
Finland & 6.4 & 5.1 & 4.0 \\
France & 4.8 & 4.1 & 3.7 \\
Austria & 3.1 & 2.7 & 3.3 \\
Russia & n.a. & 1.7 & 2.6 \\
Brazil & 1.9 & 1.9 & 2.5 \\
\hline \hline \multicolumn{2}{c}{ Data source: UN Comtrade. }
\end{tabular}

construction). This may be explained by long-time established forest industries benefiting from abundant local resources adapted to market needs, and using an efficient production tool. Nevertheless, in developed countries, only Austria, Germany and Poland won market shares between 1995 and 2011, as well as Sweden between 2000 and 2011 (Table 1). On the opposite, Canada, the USA, Finland and France have lost market shares because of lower than average export performance. Especially, Canada's exports decreased by $18 \%$ between 2000 and 2011, mainly because of the fall of the US housing market and the decrease of exports to Japan. During the same period, emerging countries (China, Russia, Brazil) and former East-Europe countries (Poland) have been more and more integrated in the world trade of wood products. While China's market share was very low in 1995 (1,4\% of world exports), this country became the most important exporter of wood products in value in 2011, which is consistent with its dynamic position in general in export markets of manufactured products. During this time period, China's exports in wood products have been multiplied by 8 with, in particularly, a high performance for exporting wooden furniture and woodworking products (panels, parquets).

In terms of net exports, France and the USA have a negative trade balance in wood products, respectively $-16,7$ and $-9,1$ billion dollars in 2011 due to a high level of imports, in particular in wooden furniture and woodworking products (Figure 2). While France has slightly improved its trade balance in forest and wood products in the mid 1990's, the deficit has strongly deteriorated since 2000 and has reached a peak in 2010 (Uusivuori and Tervo 2002, Levet et al. 2014). This is mainly due to higher imports of woodworking products in order to respond to the wood construction development as well as because of increasing imports of wooden furniture. The other main exporters register a positive trade balance. However, because of the decrease of its exports between 2000 and 2011, Canada's trade surplus has deteriorated during the same period. Nevertheless, this country still has a significantly positive trade balance ( +16 billion dollars in 2011) because of relatively low im- 


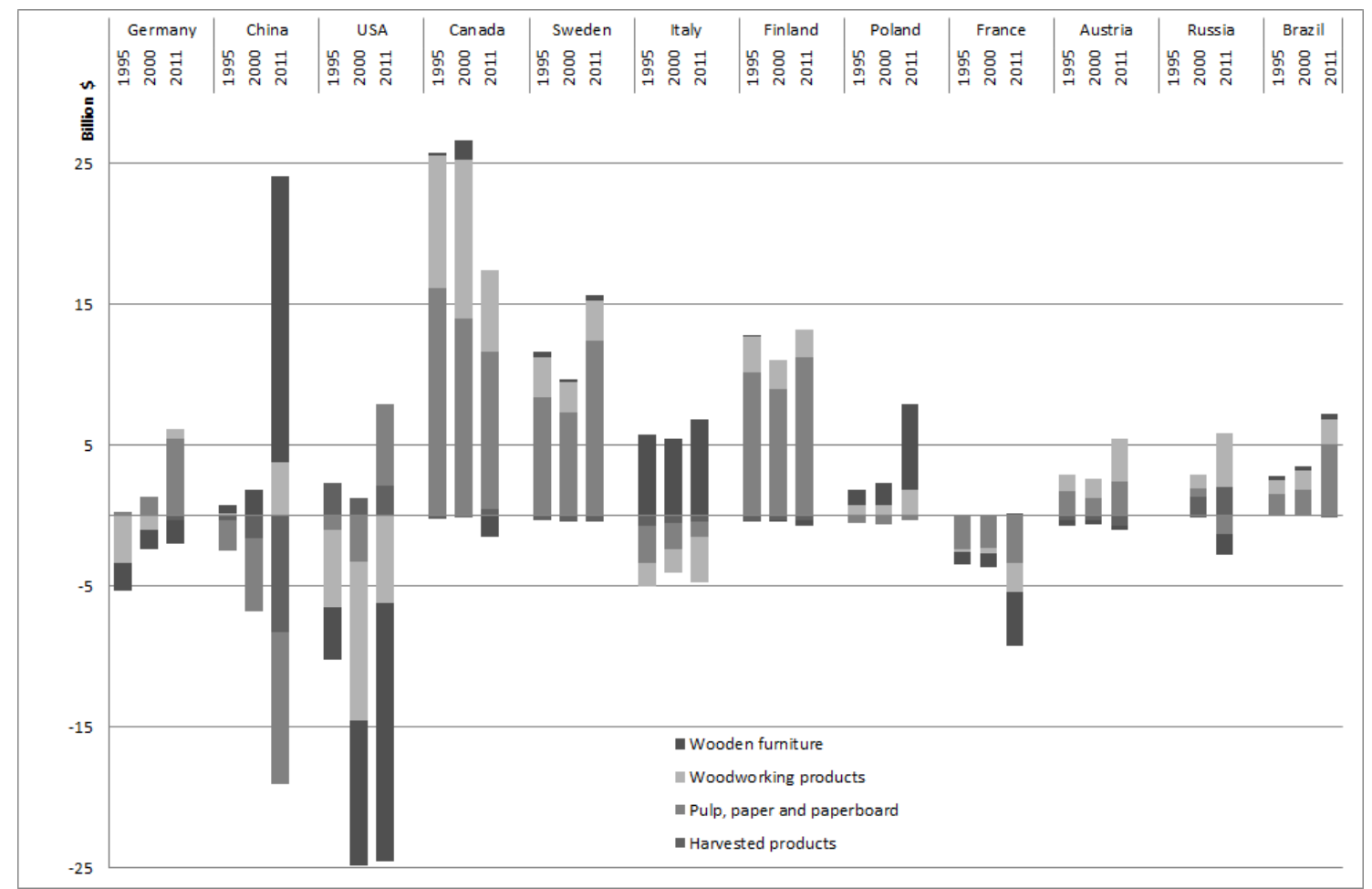

Figure 2: Trade balance for forest products and main exporters. Data source: UN Comtrade.

ports. Despite the fact that China became the most important exporter, its trade surplus $(+5,0$ billion dollars in 2011) is still significantly lower than the one observed for other countries (Canada, Sweden, Finland). Due to its relatively low resource endowment, China has to import harvested wood products which provide the raw material to the processing industries (panel, furniture). Figure 2 also shows an improvement of Germany's trade balance: starting from a trade deficit in the 1990's, this country became a net exporter of woodworking products (sawnwood, elements of construction) at the end of the period.

\section{Data}

Yearly data were collected from several sources: UN Comtrade (for total net exports of forest-based and wood products), Euklems (total factor productivity), World Bank (GDP), FAOSTAT (production and consumption of timber) and Eurostat (for other variables). Three subsectors are considered: pulp and paper products, wooden furniture, and woodworking products. ${ }^{1}$

The data cover 15 European countries (Austria, Belgium, Czech Republic, Denmark, Germany, Finland, France, Hungary, Ireland, Italy, the Netherlands, Slovenia, Spain, Sweden, and the UK) for the period 1995-2007. The list of countries for which data are available depend on the sub-sector considered. More precisely, for the wooden furniture subsector, two countries (Belgium and Sweden) were missing

\footnotetext{
${ }^{1}$ We could not include the harvested products subsector for the reason of data unavailability.
} 
from the above list of 15 countries. The woodworking sub-sector includes all the 15 countries. For the pulp and paper subsector, there are 14 countries, only Belgium being excluded from the regressions. Countries outside Europe (USA, Canada, China...) were not included in the empirical tests due to the lack of data for some industrial performance indicators (TFP).

The different data sources allow us to construct a sample that includes all the variables of interest. We consider the trade balance, Tbal, as our explained variable. It is defined as the difference between exports and imports. The gross domestic product $(G D P)$ is used to proxy the domestic demand for wood products. We expect that an increase in GDP rises the demand for wood products, leading to a deterioration of the trade balance for these products. Several variables are used to capture resource endowment and measure the relative advantage of a country compared to others. In terms of forest products, we use either production of roundwood $(\operatorname{Prod} R W)$ and net exports of roundwood $(\operatorname{Exp} R W)$, or consumption of roundwood $(C o n s R W)$. We observe that $\operatorname{Prod} R W, \operatorname{Exp} P R W$, and ConsRW cannot be used simultaneously in the same regression because they are colinear. We also retain production of wood-based panels $(\operatorname{Prod} W P)$ or consumption of wood-based panels $(C o n s W P)$ as alternative measures for resource endowment for the wooden furniture subsector due to its position at the end of the production chain. Indeed, the most important part of wood consumption by furniture manufacturers is currently made of wood-based panels and not directly of raw wood.

To control for other determinants of trade performance than those highlighted by the HOV hypothesis, we also include variables reflecting the production structure, market conditions and cost structure of the wood industries. Factors thought to have an influence on trade performance are total factor productivity $(T F P)$, average labor cost $(L C)$, and average production value per firm $(Y / N)$. Descriptive statistics for these variables are reported in Table 2. This table reports that the average firm size is much bigger in the pulp and paper industry in comparison to wooden furniture and woodworking products. However, we also observe a lot of heterogeneity over countries (we found that Austria, Finland, Germany and Sweden are the countries with the biggest firms in the pulp and paper industry). Using our panel data notation, $(Y / N)_{i t}, T F P_{i t}$ and $L C_{i t}$ provide the basis to evaluate the difference of production structure, market condition and cost structure between countries (cross-section dimension) and the dynamics of these factors (time dimension). 
Table 2: Descriptive statistics

\begin{tabular}{lrrrrr}
\hline \hline Variable & Obs. & Mean & Std. Dev. & Min. & Max. \\
\hline Pulp and paper products & & & \\
Tbal & 156 & 0.29 & 5.66 & -8.27 & 14.88 \\
ProdRW & 156 & 22.30 & 23.94 & 0.84 & 98.20 \\
Cons $R W$ & 156 & 24.50 & 25.52 & 0.70 & 103.92 \\
ExpRW & 156 & -2.20 & 4.10 & -15.46 & 3.82 \\
GDP & 156 & 0.73 & 0.75 & 0.03 & 2.92 \\
TFP & 156 & 2.94 & 2.86 & 1.84 & 17.83 \\
LC & 156 & 35.96 & 12.43 & 7.20 & 61 \\
$Y / N$ & 156 & 15.75 & 17.78 & 1.48 & 75.48 \\
\hline Wooden furniture & & & & \\
Tbal & 143 & -0.07 & 0.54 & -1.95 & 1.17 \\
ProdRW & 143 & 18.65 & 20.69 & 0.84 & 76.73 \\
ConsRW & 143 & 20.50 & 21.77 & 0.70 & 74.19 \\
ExpRW & 143 & -1.85 & 4.01 & -15.46 & 3.82 \\
ProdWP & 143 & 3.19 & 3.71 & 0.01 & 17.71 \\
ConsWP & 143 & 3.27 & 3.41 & 0.30 & 14.84 \\
GDP & 143 & 0.77 & 0.76 & 0.03 & 2.92 \\
TFP & 143 & 2.37 & 0.40 & 1.52 & 4.29 \\
LC & 143 & 24.96 & 9.16 & 3.50 & 42.20 \\
Y/N & 143 & 1.03 & 0.74 & 0.11 & 3.27 \\
\hline Woodworking products & & & \\
Tbal & 161 & -0.53 & 3.54 & -9.71 & 5.23 \\
ProdRW & 161 & 21.78 & 23.74 & 0.84 & 98.20 \\
Cons $W$ & 161 & 24.00 & 25.27 & 0.70 & 103.92 \\
ExpRW & 161 & -2.23 & 4.03 & -15.46 & 3.82 \\
GDP & 161 & 0.72 & 0.74 & 0.03 & 2.92 \\
TFP & 161 & 2.40 & 0.27 & 1.97 & 4.43 \\
LC & 161 & 26.34 & 9.51 & 3.40 & 46.50 \\
$Y / N$ & 161 & 1.30 & 0.91 & 0.07 & 4.11 \\
\hline \hline
\end{tabular}

Notes. Measurement units: Tbal in million tons (except for pulp and paper products sector where it is expressed in thousand tons); GDP: in thousand billion dollars; $L C$ : thousand euros/person; $Y / N$ : million euros/firm; Prod $R W$, Cons $R W$, ExpRW, ProdW P, ConsW P: million m. 


\section{A reappraisal of the Heckscher-Ohlin-Vanek hy- pothesis}

According to the Ricardian model, exposed for instance in Dornbusch, Fischer and Samuelson (1977), the theory of comparative advantages leads each country to specialize in the production of country specific products, and to trade them for goods produced exclusively in the foreign country. So, exported and imported commodities are physically different. In this context, trade imbalances are due to labour market rigidities, exchange rate misalignment, differences in technical change, transport cost or tariffs.

The theorical finding that countries specialize in the production of specific products is however contradicted by the data. Developed countries often trade similar goods which are horizontaly differentiated. The HOV model appears to be an interesting alternative for studying the pattern of trade and has been thoroughly surveyed by Feenstra (2004). For our purpose, however, the complete HOV model is intractable (as it involves the whole economy and not only the wood industries) and it relies on strong assumptions (same linear technologies and identical input prices over countries). Moreover, as noted by Feenstra (2004, p.31), with many goods and factors, the HOV model does not "keep track of the trade pattern in individual goods", but instead it aggregates the amounts of elementary factor endowments in order to compute the "factor content of trade (...) embodied in the exports and the imports of a country".

As our interest is in modelling wood industries, we instead consider a wood product specific version of the Heckscher-Ohlin-Vanek approach and begin with the product specific trade balance (net export): Tbal $_{i j t}$ where subscript $i$ denotes the country, $j$ the commodity (woodworking products, pulp and paper products, wooden furniture) and $t$ represents the time period. For simplicity we skip the indice $j$ from the notations below. Prestemon and Buongiorno (1997) and Lundmark (2010) also consider $\mathrm{Tbal}_{i j}$ as the explained variable.

Several assumptions are required by the HOV model (Leamer 1984, Prestemon and Buongiorno 1997): (i) the forest endowment is immobile between countries, (ii) markets are competitive with no barriers to trade; (iii) consumption is increasing in income; (iv) the same technology is available to all producers. Assumptions (i) to (iii) seem to be plausible when one considers trade on wood products. Indeed, the resource endowment immobility is true for most natural resources, in particular forests. Wood markets are reasonably competitive in that products can move freely across countries (except for some forest products which may have restrictions to export in some countries). Despite the fact that technologies are widely available, technological change and labour costs (which drive technological choice) are quite different from one country to another. In order to be compatible with technological specificities, Trefler (1993, 1995), Davis and Weinstein (2001) and Chakrabarti (2005) urge to explicitly consider differences in factor requirements into extended versions of the HOV model. In several cases the introduction of industry specific heterogeneity has been helpful for overcoming Leontief types of paradoxes (see Feenstra, 2004, Chapter 2, on this point). As our data exhibit such a paradox (Figure 1 ), we follow these recommendations and include country and industry specific ex- 
planatory variables reflecting labour cost, firm size and technological change into our analysis.

Regarding trade in forest products, the HOV hypothesis has been tested in few empirical studies leading to mixed results. In particular, Bonnefoi and Buongiorno (1990) found empirical support to the HOV hypothesis: the forest endowment has a strong positive effect on net trade for all considered commodities (roundwood, sawnwood, wood-based panels, pulp and paper). Prestemon and Buongiorno (1997) tested the same model for interstate trade in the United States and found a positive relationship between the state's net exports (lumber and wood products, paper and allied products) and their forest endowment. Uusivuori and Tervo (2002) tested the Heckscher-Ohlin-Vanek model for the trade of industrial roundwood and forest products in 18 OECD countries. According to their results, the HOV hypothesis is partially confirmed. In particular, they conclude that the role of resource is becoming less important in developed countries in shaping the development of forest industries because of other relevant factors (technology, value added products). Finally, Lundmark (2010) explores which factors (forest endowment, domestic demand, energy policies) could explain differences in net trade of forest products between EU countries. The results provide mixed support to the HOV hypothesis in that the forest endowment appears as an important determinant for explaining differences in net trade but not the domestic demand. In addition, it is also important to consider other factors like renewable energy policies.

While existing empirical studies seek to explain the trade of harvested or semiprocessed products (sawnwood, panels), our paper considers finished wood products (elements of construction, furniture, etc.). In addition, our work aims to go beyond the HOV framework (which is limited to resource endowment and income) in order to include other determinants of trade performance of wood products. Thus, following Vanek (1963) and later Lundmark (2010), we propose the following formulation to reappraisal the Heckscher-Ohlin-Vanek hypothesis:

$$
\operatorname{Tbal}_{i t}=\beta_{1} R E_{i t}+\beta_{2} G D P_{i t}+\gamma x_{i t}+\lambda_{t}+\mu_{i}+\varepsilon_{i t}
$$

where the trade balance Tbal is defined as exports minus imports. Resource Endowment $(R E)$ is either production of roundwood $(\operatorname{Prod} R W)$, net exports of roundwood $(\operatorname{Exp} R W)$ or consumption of roundwood (ConsRW). In the case of wooden furniture subsector, we also use alternative measures of resource endowment such as production of wood-based panels ( ProdWP) or consumption of wood-based panels $(C o n s W P)$. According to the HOV theory, the endowment variable should have a positive linear effect on net trade of wood products (i.e. positive effects of $\operatorname{Prod} R W$, ConsRW, ProdW $P$, ConsW $P)$. As an increase in $\operatorname{Exp} R W$ represents a reduction of resource endowment, its effect on net trade of wood products should have a negative sign. Gross Domestic Product $(G D P)$ is a measure of income and should have a negative effect on the trade balance.

Further explanatory variables representing the production (and cost) structure of the country are subsumed into $x_{i t}$ and comprise total factor productivity (TFP), average labor costs $(L C)$, and average production value per firm $(Y / N)$. We expect a positive relationship between total factor productivity $(T F P)$ and the net trade as well as for the average firm size $(Y / N)$. On the contrary, we expect to find a 
negative effect of average labor costs $(L C)$ on the trade performance variable. Time effects $\lambda_{t}$ are included via year dummies in order to account for the time effects that are common to all countries (like global available forest resources, business cycles, etc.). Individual effects $\mu_{i}$ help to control for unobserved heterogeneity specific to countries. $^{2}$

\section{Results}

Tables 3-5 present the results based on specification (1) for three groups of wood products: pulp and paper, wooden furniture and woodworking products. Model 1 corresponds to the regressions which include production of roundwood ProdRW and net exports of roundwood ExpRW as measures of resource endowment. Model 2 uses consumption of roundwood ConsRW. Due to the position of the wooden furniture subsector in the production chain, two alternative measures of resource endowment are considered for this sector: production of wood-based panels ProdW $P$ and consumption of wood-based panels ConsWP.

For each model, we compute the Hausman test to compare two alternative estimators corresponding to fixed effects and random effects. The tests report that fixed effects specification is always preferred to the random effects specification. Furthermore, the variables reflecting the production and cost structure may be endogenous: an unobserved shock affecting the trade balance may also affect the TFP, LC and $Y / N$ explanatory variables. A negative shock on exports may trigger a decrease in the labor cost and in the scale of production. By construction of TFP which relies on growth accounting (in the Euklems database), productivity may also be correlated with the level of exports and be affected by unobserved shocks affecting exports. So we perform a test for the endogeneity of $T F P, L C$ and $Y / N$. The results show that these explanatory variables are endogenous in 3 out of 8 regressions considered. In the endogenous case, we used the past values of these variables as instruments (after having tested and rejected their weakness), and proceed to parameter estimation using instrumental variables (IV). When endogeneity is rejected, we report fixed effects estimates.

The estimation results show that the determinants of the trade balance are heterogenous from one industry to the other. The effect of resource endowment on Tbal is positive and significant both for the pulp and paper products and the wooden furniture industry, and independently how resource endowment is measured (ProdRW, ConsRW, ProdW $P$, or ConsW P). Nevertheless, in the case of wooden furniture, the specification including $\operatorname{Prod} W P$ as a regressor yields a better (adjusted) fit than the specification with $\operatorname{Prod} R W$, which is consistent with the production structure of this sector consuming semi-finished products (panels) as intermediate input and not directly raw wood.

Net exports of roundwood ExpRW is never significant effect, which means that wood exports are not a limiting factor for the domestic wood industry. This evidence

\footnotetext{
${ }^{2}$ We could also express the relationship (1) by dividing both left and right hand side of the equality by the production level in order to obtain a intensity term in the expression, but this also introduces endogeneity into the specification, and makes our model not easily comparable with the existing literature.
} 
Table 3: Estimation results, pulp and paper products

\begin{tabular}{|c|c|c|}
\hline & Model 1 & Model 2 \\
\hline Variable & $\begin{array}{l}\text { Coefficient } \\
\text { (Std.Err.) }\end{array}$ & $\begin{array}{l}\text { Coefficient } \\
\text { (Std.Err.) }\end{array}$ \\
\hline ProdRW & $\begin{array}{c}0.070^{* *} \\
(0.016)\end{array}$ & $\overline{-}$ \\
\hline $\operatorname{Exp} R W$ & $\begin{array}{l}-0.161 \\
(0.115)\end{array}$ & - \\
\hline ConsRW & - & $\begin{array}{c}0.072^{* *} \\
(0.018)\end{array}$ \\
\hline$G D P$ & $\begin{array}{c}-1.750^{* *} \\
(0.767)\end{array}$ & $\begin{array}{c}-1.726^{* *} \\
(0.722)\end{array}$ \\
\hline$T F P$ & $\begin{array}{l}-0.073 \\
(0.081)\end{array}$ & $\begin{array}{l}-0.074 \\
(0.078)\end{array}$ \\
\hline$L C$ & $\begin{array}{l}-0.028 \\
(0.076)\end{array}$ & $\begin{array}{l}-0.005 \\
(0.066)\end{array}$ \\
\hline$Y / N$ & $\begin{array}{l}-0.060 \\
(0.061)\end{array}$ & $\begin{array}{l}-0.030 \\
(0.059)\end{array}$ \\
\hline Adjusted $R^{2}$ & 0.066 & 0.154 \\
\hline Number of countries & 14 & 14 \\
\hline Number of obs. & 138 & 138 \\
\hline$F$ test for weak instrument, TFP & $30.73^{* *}$ & $30.52^{* *}$ \\
\hline$F$ test for weak instrument, $L C$ & $29.60^{* *}$ & $31.64^{* *}$ \\
\hline$F$ test for weak instrument, $Y / N$ & $5.77^{* *}$ & $6.70^{* *}$ \\
\hline Endogeneity $\chi^{2}(3)$ test & $8.34^{* *}$ & $7.97^{* *}$ \\
\hline
\end{tabular}

Notes. Dependent variable: Tbal. Regression includes country and time dummies (not reported here). A Chi-squared test was performed for endogeneity of $T F P, L C$ and $Y / N$ based on a twostep IV estimator (see Schaffer, 2010). Results correspond to the fixed effects estimator, using instruments when the tests reject the exogeneity of the regressors. $*$ and ${ }^{* *}$ denote significance at the $10 \%$ and $5 \%$ levels, respectively. 
Table 4: Estimation results of the HOV model, wooden furniture

\begin{tabular}{|c|c|c|c|c|}
\hline & Model 1a & Model 2a & Model 1b & Model 2b \\
\hline Variable & $\begin{array}{l}\text { Coefficient } \\
\text { (Std.Err.) }\end{array}$ & $\begin{array}{l}\text { Coefficient } \\
\text { (Std.Err.) }\end{array}$ & $\begin{array}{c}\text { Coefficient } \\
\text { (Std.Err.) }\end{array}$ & $\begin{array}{c}\text { Coefficient } \\
\text { (Std.Err.) }\end{array}$ \\
\hline ProdRW & $\begin{array}{c}0.017^{* *} \\
(0.004)\end{array}$ & - & - & - \\
\hline $\operatorname{ExpRW}$ & $\begin{array}{l}-0.004 \\
(0.015)\end{array}$ & - & - & - \\
\hline ConsRW & - & $\begin{array}{c}0.016^{* *} \\
(0.004)\end{array}$ & - & - \\
\hline ProdWP & - & - & $\begin{array}{c}0.178^{* *} \\
(0.030)\end{array}$ & - \\
\hline ConsWP & - & - & - & $\begin{array}{c}0.174^{* *} \\
(0.045)\end{array}$ \\
\hline$G D P$ & $\begin{array}{c}-0.864^{* *} \\
(0.147)\end{array}$ & $\begin{array}{c}-0.808^{* *} \\
(0.132)\end{array}$ & $\begin{array}{c}-1.258^{* *} \\
(0.143)\end{array}$ & $\begin{array}{c}-1.200^{* *} \\
(0.164)\end{array}$ \\
\hline$T F P$ & $\begin{array}{c}-0.357^{* *} \\
(0.062)\end{array}$ & $\begin{array}{c}-0.360^{* *} \\
(0.062)\end{array}$ & $\begin{array}{c}-0.309^{* *} \\
(0.058)\end{array}$ & $\begin{array}{c}-0.344^{* *} \\
(0.062)\end{array}$ \\
\hline$L C$ & $\begin{array}{c}-0.020^{* *} \\
(0.009)\end{array}$ & $\begin{array}{c}-0.020^{* *} \\
(0.009)\end{array}$ & $\begin{array}{c}-0.015^{*} \\
(0.009)\end{array}$ & $\begin{array}{c}-0.020^{* *} \\
(0.009)\end{array}$ \\
\hline$Y / N$ & $\begin{array}{c}0.080 \\
(0.085)\end{array}$ & $\begin{array}{c}0.093 \\
(0.084)\end{array}$ & $\begin{array}{c}0.094 \\
(0.078)\end{array}$ & $\begin{array}{l}-0.032 \\
(0.088)\end{array}$ \\
\hline Adjusted $R^{2}$ & 0.539 & 0.540 & 0.599 & 0.537 \\
\hline Number of obs. & 143 & 143 & 143 & 143 \\
\hline Number of countries & 13 & 13 & 13 & 13 \\
\hline Hausman test & $109.12^{* *}$ & $114.51^{* *}$ & $115.64^{* *}$ & $113.95^{* *}$ \\
\hline Endog. $\chi^{2}(3)$ test & 2.66 & 2.61 & 5.24 & $6.57^{*}$ \\
\hline
\end{tabular}

Notes. Dependent variable: Tbal. Regression includes country and time dummies (not reported here). A Chi-squared test was performed for endogeneity of TFP, $L C$, and $Y / N$ based on a two-step IV estimator (see Schaffer, 2010). Results correspond to the fixed effects estimator as indicated by the tests for the exogeneity of the regressors and the Hausman tests comparing the random effects estimator to the fixed effects estimator. ${ }^{*}$ and ${ }^{* *}$ denote significance at the $10 \%$ and $5 \%$ levels, respectively. 
Table 5: Estimation results of the HOV model, woodworking products

\begin{tabular}{lcc}
\hline \hline & Model 1 & Model 2 \\
\hline Variable & $\begin{array}{c}\text { Coefficient } \\
\text { (Std.Err.) }\end{array}$ & $\begin{array}{c}\text { Coefficient } \\
\text { (Std.Err.) }\end{array}$ \\
\hline ProdRW & 0.003 & - \\
ExpRW & $(0.021)$ & \\
Cons $R W$ & -0.017 & - \\
& $(0.064)$ & \\
GDP & - & 0.004 \\
TFP & & $(0.020)$ \\
& 0.015 & -0.000 \\
LC & $(0.727)$ & $(0.721)$ \\
& $2.001^{* *}$ & $1.968^{* *}$ \\
$Y / N$ & $(0.435)$ & $(0.406)$ \\
& $-0.167^{* *}$ & $-0.168^{* *}$ \\
Adjusted $R^{2}$ & $(0.045)$ & $(0.045)$ \\
Number of countries & 0.382 & 0.397 \\
Number of obs. & $(0.366)$ & $(0.358)$ \\
Hausman test & 16.234 & 0.240 \\
Endogeneity $\chi^{2}(3)$ test & 151 & 15 \\
\hline \hline
\end{tabular}

Notes. Dependent variable: Tbal. Regression includes country and time dummies (not reported here). A Chi-squared test was performed for endogeneity of TFP, $L C$, and $Y / N$ based on a two-step IV estimator (see Schaffer, 2010). Results correspond to the fixed effects estimator as indicated by the tests for the exogeneity of the regressors and the Hausman tests comparing the random effects estimator to the fixed effects estimator. ${ }^{*}$ and ${ }^{* *}$ denote significance at the $10 \%$ and $5 \%$ levels, respectively. 
provides support for the HOV hypothesis in the first two industries. For the woodworking products, however, the different proxy variables for resource endowment are not significant, and the HOV model does not provide a good explanatory framework for understanding the countries' trade balance in woodworking products. This result may be also due to the heterogeneity of products in this subsector. Indeed, some production (sawnwood, panels) depends on the forest resource whereas some other (elements of construction, packaging...) are more directly related to semi-finished products like sawnwood and panels. Thus, the role of the forest resource is not the same according to the position in the value chain. The GDP has the expected negative effect on trade performance, except for woodworking products for which it is nonsignificant.

We now turn to the variable reflecting the production and cost structure of the industries. We found that none of them is significant in the pulp and paper industry whose trade balance turns out to be well described by the HOV model. Nevertheless, the weakness of adjusted $R^{2}$ underlines the need to explore other determinants in addition to those considered by the HOV hypothesis. In particular, pulp industries consume more and more recovered paper in their process instead of roundwood. Furthermore, international trade of pulp and paper products also result from intragroup exchanges within multinational firms. The TFP has a significant and positive effect on trade balance for woodworking products. On the contrary, the effect of TFP variable is significantly negative for the wooden furniture industry. This last result is counterintuitive but could be explained by the existence of furniture manufacturers producing high value products with a low productivity and exporting to niche markets. The impact of labor cost $L C$ on Tbal is negative and significant for both the wooden furniture and the woodworking industries. Labour cost plays a greater importance in woodworking industry. It also turns out that the average firm size is never significant.

In summary, empirical tests conducted in this study show some limits to the use of HOV model for explaining wood products international trade. First, roundwood consumption, which includes imports of roundwood from abroad, also exhibits the same statistical significance as the roundwood production. It turns out that in most HOV-type approaches, the forest endowment variables do not correspond exclusively to local forest resources but also proxy for the easiness to access to raw material for forest industries. In addition, in the furniture sector, the panel production, which is a semi-processed wood product, is more significant than the roundwood production. This can be explained by the growing share of furniture produced from panels (particle board, medium-density fiberboard) and the less importance of furniture produced from sawnwood. But it also suggests that the more the wood product is transformed, the less its production depends directly on the local resource endowment. Second, the empirical results highlight the role of industrial performance through TFP and $L C$, which are a significant determinant for explaining differences net trade of in furniture and woodworking products. Third, the overall fit of the model (measured by adjusted $R^{2}$ ) is relatively low according to the groups of wood products (from $7 \%$ to $60 \%$ ). This suggests that only a (small) part of the determinant factors has been captured in the model, which needs to explore other factors, in particular beyond the resource endowment. These results are somewhat different 
from Prestemon and Buongiorno (1997) and Lundmark (2010) who found a higher adjusted $R^{2}$ (from $35 \%$ to $90 \%$ ). One explanation could be that these previous studies focus on semi-transformed products whereas the current paper includes mainly finished wood products.

\section{Conclusion}

The purpose of this paper was to estimate a version of the Heckscher-Ohlin-Vanek theory for international trade in wood products, including finished wood products. In particular, we analyze the role of forest resource endowment for explaining wood products trade. Beyond the resource endowment, we also investigate the role of further variables reflecting the industrial performance of sectors. For this purpose, an extended specification of the HOV model is considered and empirically estimated for European countries and three groups of wood products.

The results show that the forest resource endowment, measured by the roundwood production (or consumption), is a significant determinant for explaining differences in net trade for two groups of wood products: pulp and paper and furniture. According to these results which are consistent with the HOV predictions, increasing the production (consumption) of roundwood fosters the net exports of pulp and paper and furniture. However, our extended specification of the HOV model shows that the forest endowment variable does not explain the trade patterns of woodworking products, but that industrial indicators like total factor productivity and average labor costs, have an influence on trade performance for this industry: countries with lower labour cost and high productivity exhibit in average a positive trade balance in comparison to other countries.

Therefore, it appears that the endowment variable is not sufficient to explain trade patterns of wood (finished) products and highlights the needs for exploring other factors. Such results had already been underlined in Uusivuori and Tervo (2002) about the role of the technological development of industries and in Lundmark (2010) about the role of energy policies. In this paper, we show that both endowments and industry specific variables have to be considered for understanding trade, but their relative importance depends on the industry considered. In terms of public policies, this could lead to recommend that incentive measures designed to foster forest industries should not only focus on resource mobilization but also on the improvement of industrial performance of transformed products sectors. In addition, the relatively heterogeneity of results between the three sectors considered should conduct to adopt specific and adapted approaches to each sector.

A limitation of this work is the high level of aggregation we considered. With industry specific data, it is not possible to observe the firm level dynamics and we have to rely on the hypothesis of a representative firm for our inference. For instance, if high value added and high wage firms export more than average (a stylized fact highlighted by Bernard et al. 2007) and coexist with nonexporting small firms producing standardized products at a lower wage, then an aggregate analysis cannot identify the relationships of interest between export activity, productivity and labour cost. The role of industrial performance could be more deeply analyzed by using other trade models based on firm heterogeneity (Melitz, 2003, Eaton et 
al., 2011) and firm data. A complementary study of export behavior in the wood sectors based on firm data is proposed by Koebel et al. (2015).

\section{Acknowledgement}

This research was financially supported by the GIP ECOFOR. We would like to thank the participants of the seminars at Nancy, Paris, Rennes, Strasbourg and Uppsala. We are also indebted to two anonymous referees for useful comments on a previous version.

\section{Appendix}

Table A1: List of wood products

\begin{tabular}{llll}
\hline \hline Harvested products & Woodworking products & Pulp and paper & Wooden furniture \\
\hline Roundwood, sawlogs, & Sawnwood & Pulp & Kitchen furniture \\
wood fuel, ... & Veneer sheets & Paper \& paperboard & Furniture for dining-room, \\
Other forest products & \& wood-based panels & & living-room, ... \\
& Packaging & Office furniture \\
& Parquets & \\
& Carpentry and joinery & & \\
& Miscellaneous & \\
\hline \hline
\end{tabular}

Table A2: Sources and definitions of the variables

\begin{tabular}{lll}
\hline \hline Variable name & Definition & Nature \\
\hline Tbal & $\begin{array}{l}\text { Trade balance (exports minus imports), in million tons } \\
\text { (in thousand tons for pulp and paper products sector) }\end{array}$ & UN COMTRADE \\
ProdRW & Production of roundwood, in million m3 & FAOSTAT \\
Exp $R W$ & Net exports of roundwood, in million m3 & FAOSTAT \\
Cons $W W$ & Apparent consumption of roundwood, in million m3 & FAOSTAT \\
ProdWP & Production of wood-based panels, in million m3 & FAOSTAT \\
Cons $W P$ & Apparent consumption of wood-based panels, in million m3 & FAOSTAT \\
$G D P$ & Gross domestic product in PPP, in thousand billion dollars & World Bank \\
$T F P$ & Total factor productivity (index) & EU Klems \\
$L C$ & Average labor cost, in thousand euros/person & Eurostat \\
$Y / N$ & Average production value per firm, in million euros/firm & Eurostat \\
\hline \hline
\end{tabular}

\section{References}

[1] Bernard, A. B., J. B. Jensen, S. J. Redding, and P. K. Schott. (2007), "Firms in International Trade," Journal of Economic Perspectives, 21, 105-130.

[2] Bonnefoi B., Buongiorno J. (1990), "Comparative advantage of countries in forest-products trade," Forest Ecology and Management, 36, 1-17. 
[3] Brecher, R. A. and E. U. Choudhri (1982), "The Leontief Paradox, Continued," Journal of Political Economy, 90, 820-23.

[4] Davis D. R. and D. E. Weinstein (2001), "An Account of Global Factor Trade," American Economic Review, 91, 1423-1453.

[5] Dornbusch, R., S. Fischer and P. A. Samuelson. (1977), "Comparative Advantage, Trade, and Payments in a Ricardian Model with a Continuum of Goods," American Economic Review, 67, 823-839.

[6] Eaton J., Kortum S., Kramarz F. (2011), "An anatomy of international trade: evidence from French firms," Econometrica, 79, 1453-1498.

[7] Eurostat database, Structural business statistics, http://ec.europa.eu/eurostat/fr/data/database

[8] FAOSTAT database, Forestry Production and Trade, http://faostat3.fao.org/download/F/FO/E

[9] Feenstra, R. C. (2004), Advanced International Trade, Princeton University Press.

[10] Heckscher E. (1919), "The effects of foreign trade on the distribution of income," Ekonomisk Tidskriff 21, 1-32.

[11] Koebel B.M., Levet A.-L., Nguyen-Van P., Olland F. (2015), "Fixed costs, trade and total factor productivity in the French wood sector," unpublished manuscript, University of Strasbourg.

[12] Krugman P.R., Obstfeld M., Melitz M. (2011), International Economics: Theory and Policy, 9th edition, Addison-Wesley.

[13] Leamer E.E. (1980), "The Leontief Paradox, Reconsidered," Journal of Political Economy, 88, 495-503.

[14] Leamer E.E. (1984), Sources of International Comparative Advantage, MIT Press.

[15] Levet A.L., Guinard L., Purohoo I. (2014), "Le commerce extérieur des produits bois: existe t-il réellement un paradoxe français? / Foreign trade in wood products: is there truly a French paradox?, Revue Forestière Française, 66, 51-66.

[16] Lundmark R. (2010), "European trade in forest products and fuels," Journal of Forest Economics 16, 235-251.

[17] Melitz M. (2003), "The impacts of trade on intra-industry reallocations and aggregate industry productivity", Econometrica, 71, 1695-1725.

[18] Ohlin B. (1933), Interregional and International Trade, Harvard University Press. 
[19] O’Mahony M., Timmer M.P. (2009), "Output, input and productivity measures at the industry level: the EU Klems database", The Economic Journal, 119, 374-403.

[20] Prestemon J.P., Buongiorno J. (1997), "Comparative advantage in US interstate forest products trade," Journal of Forest Economics 3, 207-228.

[21] Schaffer M.E. (2010), "xtivreg2: Stata module to perform extended IV/2SLS, GMM and AC/HAC, LIML and $k$-class regression for panel data models," http://ideas.repec.org/c/boc/bocode/s456501.html

[22] Timmer M., T. van Moergastel, E. Stuivenwold, G. Ypma , M. O’Mahony and M. Kangasniemi (2007), "EU Klems growth and productivity accounts," Part 1 Methodology. available at http://www.euklems.net.

[23] Trefler, D., (1993), "International Factor Price Differences: Leontief was Right!," Journal of Political Economy, 101, 961-987.

[24] Trefler, D., (1995), "The Case of the Missing Trade and Other Mysteries," American Economic Review, 85, 1029-1046.

[25] UN Comtrade, International Trade Statistics Database, http://comtrade.un.org.

[26] Uusivuori J., Tervo M. (2002), "Comparative advantage and forest endowment in forest products trade: Evidence from panel data of OECD countries," Journal of Forest Economics 8, 53-75.

[27] Vanek J. (1963), The Natural Resources Content of United States Foreign Trade, 1870-1955. MIT Press.

[28] Vanek J. (1968), "The factor proportions theory: The $\mathrm{n}$ factor case," Kyklos $21,749-756$. 